\section{Sick Sinus Syndrome}

SIR,-There are two points in your leading article on sinuatrial disorder (23 June, $p$. 677) which require comment. The familial nature of this disorder requires stressing since it is not only in the younger relatives that it can be asymptomatic. ${ }^{1}$ Moreover, not all affected patients fail to develop a tachycardia on exercise, and older and affected siblings may neglect their symptoms until cerebral or cardiac catastrophes oocur. Barlier diagnosis by careful screening of the families of affected patients using simple clinical methods 1 can prevent unnecessary cardiac and cerebral neurosis and allow planned follow-up of the asymptomatic but affected patients and then earlier provision of effec tive treatment when symptoms do occur.

Although angina caused by persistence of bradycardia during exercise and rest has been described as an aetiological factor for the anginal symptoms and cerebral disturbances of John Hunter, ${ }^{2}$ your leading article surely misplaced one reference source. ${ }^{3}$ This communication, the first to use the term sinuatrial disorder in 1971, suggested that acute hyperextension of the neck causing indirect trauma to the sinuatrial node may be a more common contributory cause of death in patients with closed head injury than is at present recognized.-I am, etc.,

\section{Department of Geriatrics,
King's College Hoopital, \\ 1 Livesley, B., Catley, P. F., and Oram, S., British Heart Youmal, 1972, 34, 668.
Livesley, B., Medical History, 1973, 1. 70.} 2 Livesley, B., Medical History, 1973, 1. 70. 226.

\section{Spastic Quadriplegia due to Electric Shock}

SIR,-I read with interest the article by Drs. S. C. So and M. L. K. Lee (9 June, p. 590) and I was surprised to read in the opening sentence that they were unaware that the sequence of non-progressive permanent spastic quadriplegia with noticeable wasting of the small muscles of the hand after electric shock had previously been recorded. There is extensive literature on the subject, the first report being by Panse in 1930.1 Subsequent accounts were given by Hyslop in $1949^{2}$ and Jackson in $1964,{ }^{3}$ and a single case was reported by Holbrook et al. in 1970.4 I know of several other cases that have occurred that have not been recorded in the literature. $-I$ am, etc.,

National Spinal Injuries Centre,

Stoke Mandeville Hospital,

1 Panse, F., Die Schädigungen des Nervensystems, durch technische Elektrizität. Berlin, Karger, 1930.

Hyslop, G. H., in Injuries of the Brain and Spinal Cord, ed. S. Brock, 3rd edn., p. 660 . London, Baillere, Tindall, and Cox, 1949.

Jackson, F. E., Martin, R., and Davis, R., in Proceedings of 13th Annual Clinical Spinal Cor Injury Conference, p. 40, Richmond,

4 Holbrook. L. A., Beach, F. X., and Silver, J. A.
British Medical foumal, 1970, 4, 659.

\section{Prescribing Mandrax}

Sin,-One would have hoped that most doctors, by studying the recent correspondence in your columns appearing prior to 23 June, would have reached a balanced assessment regarding the prescribing of
Mandrax. However, Dr. W. W. Sargant (23 June, p. 716) writes that he has "finally fallen back in the last 500 or more patients on the use of Mandrax or methaqualone in preference to other sedatives," to be given in association with electric convulsion therapy. He suggests that "if any 'committee" doctor would like to check up on clinical realities" he should consult the "hundreds and hundreds" of clinical records of these patients, the information, he implies, being available in the book of which he is coauthor.?

Though not a "committee doctor" I accepted the invitation to "check up" and consulted the reference given. I found 13 lines on Mandrax in a chapter on "Chemical Sedation and Stimulation" and two lines on combining Mandrax with a tricyclic antidepressant for sleep. The clinical records of "hundreds and hundreds" of parients treated with Mandrax are clearly not available there. and there is no critical assessment of Mandrax as used in the combined therapy described in the chapter on "Modified Narcosis."

In his letter Dr. Sargant produces his own definition of addiction in order to assert that "no addiction [to Mandrax] has been seen" except in that important group including the young, psychopaths, and very ill depressed people!

Dr. Sargant pleads for no more drug bans. I would hope that, in view of the outstanding achievement of the voluntary ban on amphetamine prescribing, similar if not more stringent measures to prevent the increasing misuse of Mandrax should be encouraged. -I am, etc.,

HenRy Matthew

Regional Poisoning Treatment Centre,

The Royal Infirmary,

\section{Sarzant, W., and Slater, B., An Introduction to Physical Methods of Treatmont in Psychiatry Livingstone, 1972.}

SIR,-How refreshing it is to see the sensible letter from Dr. W. W. Sargant on the above subject (23 June, p. 716). I agree with every word that Dr. Sargant writes about the usefulness of both Mandrax and methaqualone. Properly prescribed, these drugs are extremely valuable in the practice of psychiatry. It seems to me to be completely inconsistent that they are now being regarded in a worse light than the far more dangerous barbiturates.

I would also like to support Dr. Sargant in hoping that there will be no more drug bans. The abuse of beneficial drugs by a small minority of psychopathic and immature personalities should not lead to a situation where patients who might benefit from useful drugs are deprived of them because doctors become frightened of the drugs falling into the wrong hands. As far as Mandrax and methaqualone are concerned the scare campaign against them appears to me to have been grossly exaggerated in the medical, lay, and even the underground press. I see a fair number of young people who have at times abused these drugs, but I find that the results of so doing are not nearly as severe as those due to barbiturate dependence and/or addiction.-I am, etc.,

\section{IEWIS CIEN}

\section{Confidentiality}

SIR,-I refer to your tape-recorded discussion on confidentiality (23 June, p. 700). Lord Eldon's remark in 1820 about restrictions placed on the publication of diaries by physicians of King George III was referred to in a recent divorce action. It was also said that members of the royal family had required their staff to enter into covenants restraining them from writing anything they learn while in service. Randolph Churchill was reported as having remarked, "It looks as if eminent people would be well advised in future to enter into similar covenants with their physicians."2-I am, etc.,

W. K. BERNFEID

Cardif

1 Arsyll v. Areyll, All England Law Reports, 1965, 1,61. Areld, W. K., The Cambrian Law Review,
1972, 3, 26.

\section{Complaints against Doctors}

SIR,-I see from your leading article (30 June, p. 729) that once again the emphasis is on complaints against doctors, with thought being given to all the various methods used to regulate the profession. I am looking forward to the happy day when the B.M.A. gives more than lip-service to securing a realistic contract for the family doctor, including regulation of the patient. -I am, etc.,

Lincoln

K. C. Beswick

SIR,-It must be a source of distress to all to read that complaints nowadays are chiefly about the manners and remarks of practitioners and their receptionists (leading article, 30 June, p. 729). However, a nation that has for 25 years despised the aristocratic tradition, decried discipline in schools, universities, and elsewhere, and derided the bedside manner as old-fashioned and unscientific can hardly be surprised if they are not now always treated with old-world courtesy by perfect ladies and gentlemen.-I am, etc.,

Newick, Sussex

J. R. CAIDWEII

\section{Dangers of Corn Starch Powder}

SIR,-You raise two very relevant questions at the end of your leading article (2 June, p. 502): "Is it really necessary for powder to be applied to the outer surface of the gloves by the manufacturers? Is lubricant powder necessary at all?" I can think of one reason only, which is that gloves are now sterilized at a central depot and supplied dry to the theatres and wards. Powder is necessary to lubricate dry gloves.

When I was a surgical dresser on Sir Percy Sargent's firm at St. Thomas's in 1931 we never used dry gloves. The gloves, which were boiled, were filled by the surgeons and dressers with water and the hands easily introduced. I do not understand why we cannot return to this method of lubrication. Water does not cause peritoneal irritation. -I am, etc.,

S. V. HUMPHRIES 